\title{
Planting Method, Plastic Mulch, and Fumigation Influence Growth, Yield, and Root Structure of Watermelon
}

\author{
Daniel S. Egel and Ray Martyn \\ Department of Botany and Plant Pathology, Purdue University, 915 West \\ State Street, West Lafayette, IN 47907-2054
}

\author{
Chris Gunter ${ }^{1,2}$ \\ Department of Horticulture and Landscape Architecture, Purdue University, \\ 915 West State Street, West Lafayette, IN 47907-2054
}

Additional index words. Citrullus lanatus, transplants, direct-seeded, methyl bromide, root architecture, tap root

\begin{abstract}
A 2-year field study was conducted to determine the influence of planting method, i.e., transplanting or direct seeding, black plastic mulch, and soil fumigation on the vine growth, yield, and root structure of diploid hybrid watermelon. The experiment was a split-plot design with fumigation as the main plot and there were four replications. Methyl bromide $\left(337 \mathrm{~L} \cdot \mathrm{ha}^{-1}\right)$ was applied to the soil, which was then tarped. Black plastic mulch, $0.61 \mathrm{~m}$ wide $\times 2$ mil (Visqueen $4020^{\mathrm{TM}}$ ) was applied to appropriate rows. Vine growth was measured during the season and yield was determined by the number and weight of fruit from each treatment. After fruit harvest, plant roots were excavated so that root structure was maintained with minimal damage and roots were photographed. Root systems were scored for tap root dominance and overall root distribution. Directseeded watermelon had more vine growth and higher yields in both years than transplanted watermelon. The advantage of direct seeding was likely the result of the growth and root expansion that occurred for these plants while the transplants were still in the greenhouse. Direct-seeded plants also displayed greater tap root dominance in each year than transplanted watermelon. Roots of both direct-seeded plants and transplants had a greater range in size distribution in both years under plastic mulch than those grown on bare ground. In late-planted watermelon, direct-seeded plants had more favorable vine growth and yield without the aberrant roots systems produced by transplants.
\end{abstract}

The last 30 years have witnessed major changes in how watermelons are grown commercially in the United States. Intensive watermelon production often involves the use of transplants, black plastic mulch, and fumigants. These production methods have the potential to increase both yield and profit. Transplants provide a more efficient use of expensive hybrid seed and also an earlier start to the season through the use of the transplant greenhouse. Similarly, black plastic mulch has replaced bare soil because it warms soil, allows earlier production, reduces weed pressure, reduces nutrient leaching, and increases

Received for publication 15 Jan. 2008. Accepted for publication 20 Mar. 2008.

This work was supported in part by a grant from the Mary S. Rice Farm Fund. The cost of publishing this paper was defrayed in part by the payment of page charges. Under postal regulations, this paper must be hereby marked advertisement solely to indicate this fact.

Journal article number 2007-18248.

We thank Robert Ellermann for maintenance of the field plots and Sara Hoke for technical assistance. ${ }^{1}$ Current address: North Carolina State University, Horticultural Science, 230 Kilgore Hall, Box 7609, Raleigh, NC 27695-7609.

${ }^{2}$ To whom reprint requests should be addressed; e-mail chris_gunter@ncsu.edu found no aberrant growth in transplants as compared with direct-seeded plants (Eigsti, 1971), another study observed that root systems of direct-seeded watermelon had large well-developed tap roots, whereas root systems of transplanted plants lacked such dominance (Elmstrom, 1973). In another study, watermelons grown from transplants had greater root length in the top $30 \mathrm{~cm}$ of the soil compared with direct-seeded watermelon (NeSmith, 1999). Early-season yields also were higher in transplants (Elmstrom, 1973; NeSmith, 1999; Olson et al., 1994). It is possible that basal roots, i.e., roots that emerge from the upper portion of the tap root, are favored by surface-applied nutrients and water during crop production (Nicola, 1998), whereas transplant production selects against a dominant tap root (Elmstrom, 1973). Thus, the use of transplants along with black plastic mulch and drip irrigation may result in a shallow, more fibrous root system. Although root pathogens may alter the distribution of root sizes (Crosby et al., 2000), fumigation is unlikely to change the root system structure.

This study compares growth characteristics, root structure, and yield of diploid hybrid watermelon that were either directseeded or transplanted in both fumigated and nonfumigated soil. In each year, the date the transplants were seeded in the greenhouse and the date of direct seeding were within 1 week of each other. This is in contrast with other studies that have compared these two planting methods by transplanting in the field at the same time as direct seeding (Elmstrom, 1973; NeSmith, 1999; Olson et al., 1994). Such studies compare plants that vary in age by weeks. Although these studies are valid comparisons; they do not reflect how these two planting methods influence production when seeding of transplants and direct seeding in the field takes place at the same time. Our conclusions from the data presented here are that direct-seeded and transplant production result in watermelon plants that are different from each other in characteristics that have not been influenced by seeding date.

The objectives of this study were to: 1) characterize the architecture and distribution of watermelon roots as affected by planting method (transplant versus direct seed), the presence or absence of black plastic mulch and fumigation; and 2) determine vine growth and yield in response to fumigation, mulch, and planting method.

\section{Materials and Methods}

Experiments were conducted in 2003 and 2004 on a commercial watermelon farm near Vincennes, IN. The soil was a Bloomfield loamy fine sand. Land was prepared, fertilized, and pests managed according to extension guidelines for watermelons (Egel et al., 2004). The experimental area was $38.4 \times 70.1 \mathrm{~m}$. Individual replicate plots were $15.25 \mathrm{~m}$ long, plants were spaced at $1.52 \mathrm{~m}$ within a row, and rows were on 1.83-m centers. Fumigation 
with methyl bromide (337 L $\left.\cdot \mathrm{ha}^{-1}\right)$ was applied in $15.25 \times 7.3-\mathrm{m}$ plots and tarped on 16 Apr. in 2003 and 15 Apr. in 2004. Tarps were removed after $14 \mathrm{~d}$ and black plastic mulch $0.61 \mathrm{~m}$ wide $\times 2$ mil thick (Visqueen $4020^{\mathrm{TM}}$; Visqueen Film Products, Richmond, VA) was laid on 7.6- $\mathrm{cm}$ raised beds on the appropriate rows by machine. The experimental design was a split plot with fumigation as the main plot; planting method and the presence of mulch were the two subplots. Planting method and mulch were completely randomized into fumigation plots. There were four replications.

Comparison between direct-seeded and transplanted watermelon plants was done by planting seeds in the field and, when emergence was observed, sowing seeds in the greenhouse for transplants. Seed of the hybrid watermelon 'Royal Sweet' (Seminis Vegetable Seeds) was direct-seeded $\approx 2.5 \mathrm{~cm}$ deep, three per hole, on 9 May 2003 and 14 May 2004. Remay cloth at $22 \mathrm{~g} \cdot \mathrm{m}^{-2}$ (Oxco., Charlotte, NC) was used to cover the seed 1 week after sowing until emergence to protect seed against birds. To avoid having to replant the direct-seeded treatments in case of germination failure, when emergence was observed (6 d later in both years), 'Royal Sweet' seed was sowed in the greenhouse for transplant purposes. Direct-seeded plants were thinned to one seedling per hole. Transplants were planted in the field $21 \mathrm{~d}$ after sowing in the greenhouse in both years.

All plants were fertilized with $112 \mathrm{Kg} \cdot \mathrm{ha}^{-1}$ of $\mathrm{N}$ as urea with an additional $78.5 \mathrm{Kg} \cdot \mathrm{ha}^{-1}$ added as $28 \%$ as a side dress in mid-June. We added $123 \mathrm{Kg} \cdot \mathrm{ha}^{-1}$ of $\mathrm{P}$ as phosphate and $202 \mathrm{Kg} \cdot \mathrm{ha}^{-1}$ of $\mathrm{K}$ as potash.

The herbicide Curbit 3EC (Gowan, Yuma, AZ) was applied between the rows at $4.7 \mathrm{~L} \cdot \mathrm{ha}^{-1}$ and Sandea (Gowan, Yuma, AZ) was applied between the rows at $0.78 \mathrm{~L} \cdot \mathrm{ha}^{-1}$ preplant. Weeds that grew during the season were pulled by hand or hoed weekly to eliminate weed interference as a factor in yield or vine growth.

Trickle irrigation, $0.83 \mathrm{~L}$ per minute per $305 \mathrm{~m}$, was used in all plots. In plots with black plastic mulch, trickle tape was laid on the soil surface immediately beneath the plastic. In the plots that remained as bare ground, the tape was placed on the soil surface and held in place with metal wires. Plants were drip irrigated every 7 to $10 \mathrm{~d}$ from planting until harvest.

In 2003, vine growth vigor was determined by counting the leaf nodes on the main stem of each plant on 3 July. Vine crosssectional area in each plot was estimated on 17 July 2003 as the product of vine height and vine width perpendicular to the row. In 2004, vine vigor was assayed on 21 June and again on 7 and 28 July. Plant stand was counted for each plot on 21 June 2004. The mean length of two arbitrarily chosen vines in each plot was measured on 21 June and 7 July 2004. On 28 July 2004, vine growth was measured (height $\times$ width) at two arbitrary points in each plot as a measure of vine vigor.

All vines were trained by hand so that the growth from one plot did not reach or overlap any other plot. This assured that, at harvest, fruit could be identified as from a particular plot. In 2003, all fruit were harvested on 18 Aug. and both the number and weight of fruit from each plot were recorded. In 2004, harvest was separated into three different dates so that the timing of fruit maturity and not just total yield could be assessed. Marketable fruit were harvested on 27 July, 6 Aug, and 13 Aug. of 2004, whereas immature fruit and culls were harvested on 13 Aug. Both the number and weight of fruit from each plot were recorded.

On 19 Aug. 2003 and again on 20 Aug. 2004 , the root systems from two plants in each plot were carefully removed by excavating a cylinder of soil surrounding the root of $\approx 36$ $\mathrm{cm}$ in diameter and depth so as to not distort the architecture of the root system and to preserve as many roots as possible. The root systems were stored at $4{ }^{\circ} \mathrm{C}$ until they could be photographed and analyzed. The root systems were rated for the presence of a prominent well-developed tap root system and the distribution of root size classes (Table 1).

Vine growth characteristics, yields, and root system scores were analyzed by factorial analysis of variance using SAS (Statistical Analysis Systems, Cary, NC). Statistical differences between treatment means were determined using a $t$ test (least significant difference, $P=0.05$ ).

\section{Results}

Although fumigation was associated with significant differences in vine growth in 2003 and 2004, yields were not significantly affected in either year. In 2003, there were significantly more leaf nodes and vine area of plants in fumigated plots than in nonfumigated plots (Table 2). In 2004, plants from the fumigation treatment had significantly more leaf nodes ( 7 July) than those in the nonfumigated plots (Table 3 ).

Plants in all black plastic mulch treatments had significantly greater vine growth and fruit yield in both 2003 and 2004 compared with those from the bare ground treatments (Tables 2, 3, and 4).

Plants that were direct-seeded outperformed transplants in both vine growth and yield in 2003 (Table 2). In 2004, there were significantly more leaf nodes on 21 June and 7 July on direct-seeded plants than on transplants. Vine length of direct-seeded treatments also was significantly greater than in transplanted treatments on 21 June (Table 3 ). Vine growth increased by almost one-third in direct-seeded watermelon between 21 June

Table 1. Tap root structure and root size distribution rating scale ${ }^{\mathrm{z}}$

\begin{tabular}{|c|c|c|c|}
\hline \multicolumn{2}{|r|}{ Tap root score } & \multicolumn{2}{|r|}{ Size distribution score } \\
\hline Rating & Description & Rating & Description \\
\hline 1 & $\begin{array}{l}\text { No tap root observable beyond } \\
\text { hypocotyl }\end{array}$ & 1 & $\begin{array}{l}\text { A few scaffold roots present; no or few } \\
\text { secondary or tertiary roots }\end{array}$ \\
\hline 2 & Tap root less than $3 \mathrm{~cm}$ long & 2 & Scaffold roots present, a few secondary roots \\
\hline 3 & $\begin{array}{l}\text { Tap root between } 3 \text { and } 10 \mathrm{~cm} \text { long } \\
\text { or if } 10 \mathrm{~cm} \text { or more is bent }\end{array}$ & 3 & $\begin{array}{l}\text { Scaffold roots present, family of sizes from } \\
\text { scaffold size down; one size class missing, } \\
\text { most often tertiary or feeder roots }\end{array}$ \\
\hline 4 & $\begin{array}{l}\text { Tap root carrot-like; } 10 \mathrm{~cm} \text { or more } \\
\text { long; no significant bends }\end{array}$ & 4 & Full family of root sizes present \\
\hline
\end{tabular}

${ }^{\mathrm{z}}$ Roots were rated at the end of the season in each year.

Table 2. The influence of fumigation, plastic mulch and planting method on node number, vine growth, and yield of Royal Sweet watermelon (2003 field test).

\begin{tabular}{|c|c|c|c|c|}
\hline \multirow[b]{2}{*}{ Treatment } & \multicolumn{2}{|c|}{ Vine growth } & \multicolumn{2}{|c|}{ Fruit yield $^{z}$} \\
\hline & Leaf nodes $^{y}$ & $\operatorname{Area}^{x}\left(m^{2}\right)$ & No./ha & $\mathrm{Kg} \cdot \mathrm{ha}^{-1}$ \\
\hline \multicolumn{5}{|l|}{ Fumigation $^{\mathrm{w}}$} \\
\hline Plus & $13.3 * \mathrm{v}$ & $0.17 *$ & 360 & 23,588 \\
\hline Minus & 10.8 & 0.14 & 338 & 21,174 \\
\hline$P$ value & 0.0038 & 0.0024 & 0.5178 & 0.3449 \\
\hline \multicolumn{5}{|l|}{ Mulch $^{\mathrm{u}}$} \\
\hline Black plastic & $14.2 *$ & $0.19 *$ & $482 *$ & $31,247^{*}$ \\
\hline Bare ground & 9.9 & 0.12 & 215 & 13,524 \\
\hline$P$ value & 0.0001 & 0.0001 & 0.0001 & 0.0001 \\
\hline \multicolumn{5}{|l|}{ Planting method ${ }^{\mathrm{t}}$} \\
\hline Seeded & $16.7 *$ & $0.21 *$ & $474^{*}$ & $31,247 *$ \\
\hline Transplanted & 7.3 & 0.10 & 221 & 13,524 \\
\hline$P$ value & 0.0001 & 0.0001 & 0.0001 & 0.0001 \\
\hline
\end{tabular}

zFruit was harvested 18 Aug. 2003.

yThe number of leaf nodes present on the main stem 3 July 2003.

${ }^{x}$ Represents a cross-section of the growth of vines (height $\times$ width) measured on 17 July 2003.

wMethyl bromide was applied 16 Apr. under the plastic at the rate of $337 \mathrm{~L} \cdot \mathrm{ha}^{-1}$.

${ }^{\mathrm{v}}$ Comparisons between treatment factors with an asterisk are statistically significant at the $5 \%$ level $[t$ test (least significant difference), $P=0.05]$.

ulack plastic mulch $0.61 \mathrm{~m}$ wide $\times 2$ mil black plastic (Visqueen 4020 ) was laid 30 Apr.

${ }^{t}$ Seeds of the diploid hybrid cultivar Royal Sweet were direct seeded 9 May $\approx 2.5 \mathrm{~cm}$ deep at the rate of three per hill and thinned 2 weeks later to one plant every $1.5 \mathrm{~m}$. When emergence of these seedlings was observed on 15 May, transplants were started in the greenhouse. Transplants were planted into the field 6 June. 
Table 3. The influence of fumigation, plastic mulch, and planting method on plant stand, node number, vine length, and vine area (2004 field test).

\begin{tabular}{|c|c|c|c|c|c|c|}
\hline \multirow[b]{2}{*}{ Treatment } & \multicolumn{3}{|c|}{21 June } & \multicolumn{2}{|c|}{7 July } & \multirow{2}{*}{$\begin{array}{c}28 \text { July } \\
\text { Area }^{\mathrm{w}}(\mathrm{m})\end{array}$} \\
\hline & Plant stand ${ }^{\mathrm{z}}$ & Leaf nodes $^{y}$ & Length $^{\mathrm{x}}(\mathrm{m})$ & Leaf nodes & $\overline{\text { Length }(\mathrm{m})}$ & \\
\hline \multicolumn{7}{|l|}{ Fumigation $^{v}$} \\
\hline Plus & 9.2 & 9.4 & 0.66 & $16.4^{* u}$ & 1.57 & $2.67^{*}$ \\
\hline Minus & 9.2 & 10.9 & 0.73 & 14.3 & 1.43 & 3.26 \\
\hline$P$ value & 0.8395 & 0.1245 & 0.3596 & 0.0402 & 0.2258 & 0.0141 \\
\hline \multicolumn{7}{|l|}{ Mulch $^{t}$} \\
\hline Black plastic & $9.8^{*}$ & $11.7^{*}$ & $0.85^{*}$ & $17.5^{*}$ & $1.77^{*}$ & $3.34 *$ \\
\hline Bare ground & 8.7 & 8.7 & 0.53 & 13.1 & 1.22 & 2.59 \\
\hline$P$ value & 0.0011 & 0.0021 & 0.0001 & 0.0001 & 0.0001 & 0.0020 \\
\hline \multicolumn{7}{|l|}{ Planting method } \\
\hline Seeded & $8.6^{*}$ & $14.8^{*}$ & $1.10^{*}$ & $16.6^{*}$ & 1.48 & $2.64 *$ \\
\hline Transplanted & 9.8 & 5.6 & 0.28 & 14.1 & 1.51 & 3.29 \\
\hline$P$ value & 0.0002 & 0.0001 & 0.0001 & 0.0138 & 0.7631 & 0.0074 \\
\hline
\end{tabular}

${ }^{2}$ Plant stand represents the number of plants present per plot.

${ }^{y}$ Leaf nodes represents the mean number of nodes on the main stem of two randomly chosen vines in each plot on the date indicated.

${ }^{x}$ Vine length represents the mean length of two randomly chosen vines in each plot in centimeters on the date indicated.

wepresents a cross-section of the growth of vines (height $\times$ width) measured on 28 July 2004.

${ }^{v}$ Methyl bromide was applied $15 \mathrm{Apr}$. under the plastic at the rate of $337 \mathrm{~L} \cdot \mathrm{ha}^{-1}$.

"Comparisons between treatment factors with an asterisk are statistically significant at the $5 \%$ level $[t$ test (least significant difference), $P=0.05]$.

'Black plastic mulch $0.61 \mathrm{~m}$ wide $\times 2$ mil black plastic (Visqueen 4020) was laid 29 Apr.

${ }^{\mathrm{s}}$ Seeds of the diploid hybrid cultivar Royal Sweet were direct-seeded 14 May $\approx 2.5 \mathrm{~cm}$ deep at the rate of three per hill and thinned 2 weeks later to one plant every $1.5 \mathrm{~m}$ feet. When emergence of these seedlings was observed on 20 May, transplants were started in the greenhouse. Transplants were planted into the field on 11 June.

and 7 July, whereas it increased more than fivefold in transplanted watermelon during the same time period (Table 3). In 2003, direct-seeded treatments significantly outyielded transplant treatments by more than twofold (Table 2). In 2004, direct-seeded plants outproduced transplants by one-third in number and weight of fruit; however, transplants outyielded direct-seeded plants on 13 Aug. by one-third in both number and weight of fruit (Table 4). Transplanted plants also had significantly more culls and fruit that were not mature on $13 \mathrm{Aug}$. than those that were direct-seeded (Table 4).

Fumigation did not appear to affect either the tap root architecture or root size distribu- tion in 2003 or 2004 (Table 5). The tap root was more pronounced on plants grown under black plastic than in bare ground in 2003; however, there was no difference in tap root architecture between the black plastic mulch and bare ground treatment in 2004 (Table 5). In both years, root sizes were more evenly distributed under black plastic than in bare ground (Table 5). Planting method had the most striking effect on root architecture. In both 2003 and 2004, direct-seeded watermelon scored significantly higher in tap root dominance over transplants (Table 5). In both years also, root sizes were more evenly distributed in the transplanted plants than those that were direct-seeded (Table 5).

\section{Discussion}

Fumigation may increase the yields of watermelon when soilborne disease problems exist or when weeds offer serious competition to a crop. In some cases, fumigation may result in higher yields even when no obvious soilborne pathogen or pest is present. In these cases, fumigation may eliminate opportunistic organisms in the soil often described as "root nibblers". "Root nibblers" may attack the young feeder roots on plants with a compromised root system such as those produced from transplants and grown under plastic mulch (Martyn, 2007). Although soilborne pathogens and pests had been observed in the field used in this present study in previous years (Egel et al., 2000), no disease pressure was observed in 2003 or 2004. In the present study, there may have been sufficient pressure from "root nibblers" to cause some differences in vine growth, but not enough to affect yield.

Most watermelon production in Indiana is under black plastic to: 1) control weeds, 2) warm the soil and increase early yields, and 3) maintain moisture in the soil. Because there was no weed interference or known soilborne pathogens, the increase in vine growth and yields observed in this study were most likely the result of the warmer and moister soil under the plastic mulch. With the exception of May 2003, the 3 months of May through July of 2003 and 2004 were all wetter than average. Also, with the exception of May 2004, all of the months of the experiment were cooler than normal. Therefore, it is likely that the greater vine growth and yield observed in this study is attributable mostly to warmer soil temperatures under the mulch.

Although direct-seeded watermelon outproduced transplanted watermelon in most vine growth characteristics and yield in 2003 and 2004, a closer examination of 2004 data reveals that seeded plants may have simply

Table 4. The influence of fumigation, plastic mulch, and planting method yield of Royal Sweet watermelon, 2004.

\begin{tabular}{|c|c|c|c|c|c|c|c|c|c|c|}
\hline \multirow[b]{3}{*}{ Treatment } & \multicolumn{8}{|c|}{ Marketable $^{\mathrm{z}}$} & \multirow{2}{*}{\multicolumn{2}{|c|}{$\begin{array}{c}\text { Culls } \\
13 \text { Aug. }\end{array}$}} \\
\hline & \multicolumn{2}{|c|}{ 27 July } & \multicolumn{2}{|c|}{6 Aug. } & \multicolumn{2}{|c|}{13 Aug. } & \multicolumn{2}{|c|}{ All dates } & & \\
\hline & No.ha ${ }^{-1}$ & $\mathrm{Kg} \cdot \mathrm{ha}^{-1}$ & $\overline{\mathrm{No} \cdot \mathrm{ha}^{-1}}$ & $\overline{K g} \cdot \mathrm{ha}^{-1}$ & $\overline{\text { No } \cdot h a^{-1}}$ & $\mathrm{Kg} \cdot \mathrm{ha}^{-1}$ & $\overline{\text { No } \cdot h a^{-1}}$ & $\mathrm{Kg} \cdot \mathrm{ha}^{-1}$ & No $\cdot$ ha $^{-1}$ & $\mathrm{Kg}^{2} \cdot \mathrm{ha}^{-1}$ \\
\hline \multicolumn{11}{|l|}{ Fumigation $^{y}$} \\
\hline Minus & 128 & 7,209 & 145 & 8,705 & 247 & 13,855 & 520 & 29,770 & 385 & 10,725 \\
\hline$P$ value & 0.0880 & 0.1475 & 0.0825 & 0.0954 & 1.000 & 0.6911 & 0.2012 & 0.1369 & 0.3948 & 0.3773 \\
\hline \multicolumn{11}{|l|}{ Mulch } \\
\hline \multicolumn{11}{|l|}{ Planting method ${ }^{\mathrm{v}}$} \\
\hline Seeded & $194 * *$ & $11,052 * *$ & $196 * *$ & $11,856^{* *}$ & 198 & 10,625 & $588 * *$ & $33,533 * *$ & $214 * *$ & $7,006^{* *}$ \\
\hline Transplanted & 29 & 1,664 & 60 & 3,588 & $296 *$ & $16,242 *$ & 385 & 21,496 & 476 & 16,138 \\
\hline$P$ value & 0.0001 & 0.0001 & 0.0001 & 0.0001 & 0.0123 & 0.0106 & 0.0003 & 0.0002 & 0.0073 & 0.0001 \\
\hline
\end{tabular}

${ }^{2}$ Marketable fruit were harvested on dates shown. Culls harvested on 13 Aug. included immature fruit.

${ }^{y}$ Methyl bromide was applied $15 \mathrm{Apr}$. under the plastic at the rate of $337 \mathrm{~L} \cdot \mathrm{ha}^{-1}$.

${ }^{w}$ Comparisons between treatment factors with an asterisk are statistically significant at the $5 \%$ level. [ $t$ test (least significant difference), $P=0.05$ ]; those comparisons with double asterisks are statistically significant at the $1 \%$ level. [ $t$ test (least significant difference), $P=0.01]$.

${ }^{x}$ Black plastic mulch $0.61 \mathrm{~m}$ wide $\times 2$ mil black plastic (Visqueen 4020 ) was laid 29 Apr.

${ }^{\mathrm{v}}$ Seeds of the diploid hybrid cultivar Royal Sweet were direct-seeded 14 May $\approx 2.5 \mathrm{~cm}$ deep at the rate of three per hill and thinned 2 weeks later to one plant every $1.5 \mathrm{~m}$. When emergence of these seedlings was observed on 20 May, transplants were started in the greenhouse. Transplants were planted into the field on 11 June. 
Table 5. The influence of fumigation, plastic mulch, and planting method on the root architecture and root size distribution of Royal Sweet watermelon, 2003 and 2004.

\begin{tabular}{|c|c|c|c|c|}
\hline \multirow[b]{2}{*}{ Treatment } & \multicolumn{2}{|c|}{2003} & \multicolumn{2}{|c|}{2004} \\
\hline & Tap root ${ }^{2}$ & $\begin{array}{c}\text { Root sizes } \\
\text { distribution }^{y}\end{array}$ & Tap root & $\begin{array}{c}\text { Root size } \\
\text { distribution }\end{array}$ \\
\hline \multicolumn{5}{|l|}{ Fumigation $^{\mathrm{x}}$} \\
\hline Plus & 2.44 & 3.01 & 2.46 & 2.19 \\
\hline Minus & 2.38 & 2.76 & 2.52 & 2.26 \\
\hline$P$ value & 0.5913 & 0.1294 & 0.5982 & 0.4522 \\
\hline \multicolumn{5}{|l|}{ Mulch $^{w}$} \\
\hline Black plastic & $2.19^{* v}$ & $3.20 *$ & 2.47 & $2.70 *$ \\
\hline Bare ground & 2.62 & 2.58 & 2.51 & 1.75 \\
\hline$P$ value & 0.0005 & 0.0003 & 0.6727 & 0.0001 \\
\hline \multicolumn{5}{|l|}{ Planting method } \\
\hline Seeded & $3.17 *$ & $2.54 *$ & $3.06 *$ & $1.97 *$ \\
\hline Transplanted & 1.64 & 3.23 & 1.92 & 2.48 \\
\hline$P$ value & 0.0001 & 0.0001 & 0.0001 & 0.0002 \\
\hline
\end{tabular}

${ }^{z}$ Tap roots were scored using the following scale: $1=$ no tap root observable; $2=\operatorname{tap}$ root less than $3 \mathrm{~cm}$ long; $3=$ tap root between 3 and $10 \mathrm{~cm}$ or if $10 \mathrm{~cm}$ or more is not linear; $4=$ tap root carrot-like, no significant bends (see Table 1).

${ }^{\mathrm{y}}$ The distribution of root sizes were scored as follows: $1=\mathrm{a}$ few scaffold roots present, no or few secondary or tertiary roots; 2 = scaffold roots present as well as a few secondary roots; $3=$ a family of root sizes from scaffold size to fine roots present, one size class is missing, most often tertiary or feeder roots; $4=$ full family of root sizes present.

${ }^{x}$ Methyl bromide was applied $16 \mathrm{Apr}$. under the plastic at the rate of $337 \mathrm{~L} \cdot \mathrm{ha}^{-1}$.

wBlack plastic mulch $0.61 \mathrm{~m}$ wide $\times 2$ mil black plastic (Visqueen 4020 ) was laid $30 \mathrm{Apr}$.

${ }^{\mathrm{v}}$ Comparisons between treatment factors with an asterisk are statistically significant at the $1 \%$ level $[t$ test (least significant difference), $P=0.05]$. Those comparisons with double asterisks are statistically significant at the $1 \%$ level [ $t$ test (least significant difference), $P=0.01]$.

"Seeds of the diploid hybrid cultivar Royal Sweet were direct seeded 9 May $\approx 2.5 \mathrm{~cm}$ deep at the rate of three per hill and thinned 2 weeks later to one plant every $1.5 \mathrm{~m}$. When emergence of these seedlings was observed 9 May, transplants were started in the greenhouse. Transplants were planted into the field 6 June.

outgrown transplanted plants in the early part of the season. Although direct-seeded watermelon had significantly more leaf nodes on 21 June and 7 July, vines were longer only on 21 June. On 28 July, transplanted watermelon overtook direct-seeded watermelon in the vine cross-sectional area. In addition, although vines of direct-seeded watermelon were more than three times longer than vines transplanted on 21 June, by 7 July, the lengths were almost equal. Marketable yields for direct-seeded plants were significantly greater than transplants for 27 July and 6 Aug. However, by 13 Aug., yields favored transplanted watermelon. The significantly greater number of culls in transplanted watermelons on 13 Aug. 2004 was likely the result of fruits from the transplanted plots that were immature but might have matured at a later harvest date.

Previous studies comparing direct-seeded and transplanted vegetables have often concluded that transplants outyield direct-seeded plants (Leskovar and Cantliffe, 1993; Olson et al., 1994). However, these studies compared greenhouse-grown transplants that were planted in the field at the same time that other plants were seeded directly. Earlier yields of watermelon were greater for transplants than direct-seeded plants, but transplants had been grown for 5 weeks before direct seeding and transplanting were conducted (Olson et al., 1994). Thus, transplants were older and better established than the direct-seeded plants. When transplants were seeded in the greenhouse at the same time that direct seeding was done in the field, only on the earliest of three planting dates did transplants outproduce direct-seeded plants (Elmstrom, 1973).

In the present study, mulch and planting method, but not fumigation, influenced root architecture and size distribution. Planting method influences the architecture of the roots directly and mulch influences roots by increased soil temperature and moisture (Soltani et al., 1995). Fumigation presumably does not influence the physical properties of the soil and, thus, would not likely influence root structure.

Whereas direct-seeded watermelons develop root systems that have strong tap roots, the small cell volume of transplant trays inhibits the development of a primary tap root in favor of a more fibrous root system. Inhibition occurs presumably because the tap root is not allowed to develop geotropically, but instead wraps around the cell of the transplant tray. When the seedlings are transplanted, the tap root typically does not recover its geotropic growth and tends to grow horizontally in the soil. Thus, the secondary roots emerge in the upper rhizosphere, giving rise to a more "fibrous" root system.

Watermelons grown on bare ground developed a significantly better tap root system in 2003 compared with those grown under plastic mulch. However, in 2004, there was no difference in the tap root orientation between mulch and bare ground. This may be the result of the relatively dry June in 2003 versus the relatively wet June in 2004. In both years, a greater distribution of root size classes developed on plants in plots that were mulched with black plastic than from bare ground treatments; it may be that root systems with sufficient moisture present in the surrounding soil are more likely to produce a full range of root size classes including small tertiary roots. In contrast, roots with less moisture available may be forced to produce a larger class of roots, which are able to grow deeper into the soil profile where moisture may be available. Transplanted watermelon roots developed a greater range of size distribution than direct-seeded watermelon in both years presumably because transplanted watermelon seedlings that are inhibited from developing a strong tap root compensate by developing more size classes.

The use of transplants in watermelon culture has some clear advantages over the use of direct-seeded plants. Relatively expensive and hard to germinate triploid watermelon seed can be germinated in the greenhouse where optimum conditions can be maintained. Transplants allow growers to seed watermelon when soil temperatures outside are still too cool for watermelon seed germination and growth, leading to earlier yields and better prices. However, in this study, watermelon that was direct-seeded in May outgrew transplants growing in the greenhouse during the same time period. Growers might benefit from growing diploid watermelon by direct seeding when soils are sufficiently warm for germination.

Although it may not be possible to directseed triploid watermelon to obtain the benefits observed here, it is likely that the effects of fumigation and mulch shown here may apply to transplanted triploids as well. Our observations are that triploid root systems are affected by transplant production in a similar fashion to diploids. Further experimentation may result in method of generating transplants without creating aberrant or restricted root systems.

\section{Literature Cited}

Baker, J.T., D.R. Earhart, M.L. Baker, F.J. Dainello, and V.A. Haby. 1998. Interactions of poultry litter, polyethylene mulch and floating row covers on triploid watermelon. HortScience 33:810-813.

Brown, J.E. and C. Channell-Butcher. 1999. Effects of row cover and black plastic mulch on yield of 'AU Producer' watermelon on hilled and flat rows. Journal of Vegetable Crop Production 5:67-71.

Crosby, K., D. Wolff, and M. Miller. 2000. Comparisons of root morphology in susceptible and tolerant melon cultivars before and after infection by Monosporascus cannonballus. HortScience 35:681-683.

Edelstein, M., R. Cohen, Y. Burger, and S. Shriber. 1999. Integrated management of sudden wilt in melons, caused by Monosporascus cannonballus, using grafting and reduced rates of methyl bromide. Plant Dis. 83:11421145.

Egel, D.S. 2000. Evaluation of fumigants for the control of Fusarium wilt and root-knot nematode of watermelon, 2000. Fungicide and nematicide tests. Report 56:N19. The American 
Phytopathological Society, St. Paul, MN. 22 Apr. 2008. <http://www.plantmanagementnetwork. org/pub/trial/fntests/vol55/>.

Egel, D.S., F. Lam, and E. Maynard. 2004. Midwest vegetable production guide for commercial growers, 2004. Purdue University (ID-56), West Lafayette, IN.

Egel, D.S., K. Rane, R. Latin, and R.D. Martyn. 2000. Mature watermelon vine decline: A disease of unknown etiology in southwestern Indiana. Plant Health Progress, 22 Apr. 2008. $<$ http://www.plantmanagementnetwork.org/ $\mathrm{pub} / \mathrm{php} / \mathrm{brief} / \mathrm{mwvd} />$. DOI: $10.1094 / \mathrm{PHP}-$ 2000-1227-01-HN.

Eigsti, O.J. 1971. A comparison of mature triploid watermelon systems of roots and crown from direct field seeded plants and transplants. HortScience 6:28. (Abstract).

Elmstrom, G.W. 1973. Watermelon root development affected by direct seeding and transplanting. HortScience 8:134-136.
Gilreath, J.P., J.W. Noling, and B.M. Santos. 2004. Methyl bromide alternatives for bell pepper (Capsicum annum) and cucumber (Cucumis sativus) rotations. Crop Prot. 23: 347-351.

Ibarra-Jimenez, L., J. Munguia-Lopez, A.J. Lozanodel Rio, and A. Zerrmeno-Gonzalez. 2005. Effect of plastic mulch and row covers on photosynthesis and yield of watermelon. Aust. J. Exp. Agr. 45:1653-1657.

Khan, V., C. Stevens, and A. Tang. 1991. Effect of Visapore row covers and polyethylene mulch on early production on watermelon. Tuskegee Horizons 2:19.

Leskovar, D.I. and D.J. Cantliffe. 1993. Comparison of plant establishment method, transplant, or direct seeding on growth and yield of bell pepper. J. Amer. Hort. Soc. 118:17-22.

Martyn, R.D. 2007. Late-season vine declines of melons: Pathological, cultural, or both? Acta Hort. 731:345-356.
Munnecke, D., F.F. Laemmlen, and J. Bricker. 1984. Soil fumigation controls sudden wilt of melon. California Agr. 38:8-9.

NeSmith, D.S. 1999. Root distribution of direct seeded and transplanted watermelon. J. Amer. Soc. Hort. Sci. 124:458-461.

Nicola, S. 1998. Understanding root systems to improve seedling quality. HortTechnology 8:544-549.

Olson, S.M., G.J. Holmuth, and R.C. Hochmuth. 1994. Effect of transplanting on earliness and total yield of watermelon. HortTechnology 4: 141-143.

Pivonia, S., R. Cohen, U. Kafkafi, I.S. Ben Zev'ev, and J. Katan. 1997. Sudden wilt of melons in southern Israel: Fungal agents and relationship with plant development. Plant Dis. 81:1264-1268.

Soltani, N., J.L. Anderson, and A.R. Hamson. 1995. Growth analysis of watermelon plants grown with mulches and row covers. J. Amer. Hort. Soc. 20:1001-1009. 